\title{
Differential effects of cannabinoid receptor agonist on social discrimination and contextual fear in amygdala and hippocampus
}

\author{
Amir Segev and Irit Akirav ${ }^{1}$ \\ Department of Psychology, University of Haifa, Haifa 31905, Israel
}

\begin{abstract}
We examined whether the cannabinoid receptor agonist WIN55,212-2 (WIN; $5 \mu \mathrm{g} /$ side) microinjected into the hippocampus or the amygdala would differentially affect memory processes in a neutral vs. an aversive task. In the aversive contextual fear task, WIN into the basolateral amygdala impaired fear acquisition/consolidation, but not retrieval. In the ventral subiculum (vSub), WIN impaired fear retrieval. In the neutral social discrimination task, WIN into the vSub impaired both acquisition/consolidation and retrieval, whereas in the medial amygdala WIN impaired acquisition. The results suggest that cannabinoid signaling differentially affects memory in a task-, region-, and memory stage-dependent manner.
\end{abstract}

Exogenous cannabinoid administration is associated with impaired functioning in a variety of learning paradigms including spatial (Lichtman and Martin 1996; Da Silva and Takahashi 2002; Wise et al. 2009; Robinson et al. 2010), fear conditioning (Pamplona and Takahashi 2006), and object recognition (Clarke et al. 2008) tasks.

We have recently found that the CB1/2 receptor agonist WIN 55,212-2 (WIN) impairs spatial learning and long-term potentiation in the CA1 area $(0.5 \mathrm{mg} / \mathrm{kg})$ (Abush and Akirav 2010). Microinjecting WIN $(5 \mu \mathrm{g} / 0.5 \mu \mathrm{L})$ into the CA1 area also resulted in impaired spatial learning, yet its effects on performance in an aversive learning task were different; WIN was found to facilitate inhibitory avoidance extinction when microinjected into the CA1 with no effect on avoidance conditioning (Abush and Akirav 2010).

The effects of exogenous acute cannabinoid treatment may have different outcomes depending on task aversiveness and brain region involved (Suzuki et al. 2004; de Oliveira Alvares et al. 2005; Varvel et al. 2005; Ganon-Elazar and Akirav 2009). In this study we used aversive and nonaversive memory tasks: contextual fear (CF) and social discrimination (SD).

Social recognition processes depend on brain regions such as the medial amygdala (MeA) which modulates the initial social encounter and formation of social memory (Ferguson et al. 2001; Bielsky and Young 2004) and the ventral hippocampus (van Wimersma Greidanus and Maigret 1996; Kogan et al. 2000).

In fear conditioning paradigms, the amygdala plays a central role in the formation and consolidation of fear-related memory traces (LeDoux 2003; Maren and Quirk 2004), whereas the hippocampus's role is to integrate the features of the context and not to form a context-shock association (Fanselow 1998).

Here, we examined the effects of WIN microinjected into the amygdala and the hippocampus on the acquisition and retrieval of a neutral learning task (i.e., SD) and an aversive learning task (i.e., CF). We hypothesized that WIN may have differential effects on learning and memory that are task-, brain region- and memory stage-dependent.

\footnotetext{
'Corresponding author.

E-mail iakirav@psy.haifa.ac.il; fax 97248249157.

Article is online at http://www.learnmem.org/cgi/doi/10.1101//m.2110511.
}

Male Sprague-Dawley rats ( $\sim 60 \mathrm{~d}$ old, $250-300 \mathrm{~g}$ ), were caged individually until $72 \mathrm{~h}$ before commencing the experiments (and then group housed) at $22^{\circ} \pm 2^{\circ} \mathrm{C}$ under 12-h light/ dark cycles. All experiments were carried out between 9:00 a.m. and 3:00 p.m. The experiments were approved by the University of Haifa Ethics and Animal Care Committee.

Rats were implanted bilaterally with a guide stainless steel guide cannula (23 gauge) aimed at the vSub (anteroposterior, $-6.5 \mathrm{~mm}$; lateral, $\pm 5.0 \mathrm{~mm}$; ventral, $-5.8 \mathrm{~mm}$ ), or the BLA (anteroposterior, $-3 \mathrm{~mm}$; lateral, $\pm 5.0 \mathrm{~mm}$; ventral, $-6.4 \mathrm{~mm}$ ), or the MeA (anteroposterior, $-2.5 \mathrm{~mm}$; lateral, $\pm 3.5 \mathrm{~mm}$; ventral, $-7.4 \mathrm{~mm}$ ).

For CF, rats received three $0.8-\mathrm{mA}, 2$-sec foot-shock delivered to the floor bars $90 \mathrm{sec}, 210 \mathrm{sec}$, and $330 \mathrm{sec}$ after animals were placed in the conditioning chamber. After $24 \mathrm{~h}$, rats were placed in the conditioning chamber and allowed to explore for $3 \mathrm{~min}$ and the duration of freezing was measured. The video images were analyzed by a computer (Dell OptiPlex GXpro) equipped with an analysis program and a macroprogram (P. Schmid, Behavioral Neurobiology Laboratory, Swiss Federal Institute of Technology, Zurich). The percentage of changed pixels between two adjacent 1-sec images was calculated and if the percentage of change in images was $<0.05 \%$, the behavior of the rat was scored as "freezing" for the respective later second.

To examine the effects of WIN on sensory-motor function, rats were microinjected with WIN or vehicle into the vSub or BLA and exposed to the open field or the pain sensitivity tests (Ganon-Elazar and Akirav 2009). In the open field, rats were placed at the corner and for a period of $5 \mathrm{~min}$, the number of rearings, time spent in the central squares, and the total distance covered was measured. In the pain sensitivity test each rat received a continuously ascending mild electric footshock (beginning at $0.0 \mathrm{~mA}$ ) via the metal grid floor to determine current thresholds for flinch responses.

For SD, the experimental adult rat was left in a large observation cage (size: $59 \times 38 \times 20 \mathrm{~cm}$ ) for $20 \mathrm{~min}$ of habituation before starting the session. During the first exposure ("sample" session), a juvenile was exposed to the adult animal for three 5-min exploration sessions with 5-min intervals. After $24 \mathrm{~h}$, the adult rat was left in the observation cage for 5 min of habituation and presented with the juvenile it had previously investigated and a novel juvenile for $5 \mathrm{~min}$ ("choice" session). The duration of investigatory behavior of the adult toward each juvenile was measured by 
two trained observers blind to the animals' treatment. A discrimination index was calculated to each adult (time on novel/total exploration time).

To examine the effects of WIN on social interaction, rats were microinjected with WIN or vehicle into the vSub or MeA and an adult male rat was presented to the tested animal for $3 \mathrm{~min}$. During the test, social behaviors were monitored for type (prosocial, a-social, and aggressive) and the total number of occurrences during the 3-min session was calculated (Shachar-Dadon et al. 2009). No aggressive behaviors were observed.

WIN (5 $\mu \mathrm{g} /$ side) and AM251 (0.3 ng/side) (Tocris) were initially dissolved in DMSO and further diluted with saline $(0.9 \%$ $\mathrm{NaCl}$ ) and Tween-80. The final concentration of DMSO and Tween 80 was $1 \%$ each. Controls were given the vehicle only. Drugs were microinjected 20 min before behavioral testing. Drug concentrations were based on previous studies (Campolongo et al. 2009; Ganon-Elazar and Akirav 2009; Abush and Akirav 2010).

Microinjection was performed bilaterally in a $0.3 \mu \mathrm{L}(\mathrm{MeA})$ or $0.5 \mu \mathrm{L}$ (BLA, vSub) volume per side delivered over 1 min using a 28-gauge injection cannula, connected via PE20 tubing to a Hamilton microsyringe driven by a microinfusion pump (PHD1000, Harvard Apparatus). The injection cannula was left in position before withdrawal for an additional $60 \mathrm{sec}$ to minimize dragging.

At the completion of the behavioral experiments animals were deeply anesthetized and microinjected into the vSub, BLA, or MeA with 0.5 or $0.3 \mu \mathrm{L}$ of India ink. Brains were removed and brain slices $(60 \mu \mathrm{m})$ were examined under a light microscope following Nissl staining to verify the cannula location (Fig. 1).

To examine the effects WIN on CF, rats were microinjected with WIN or vehicle into the vSub or BLA prior to conditioning (Fig. 2A) or prior to retrieval (Fig. 2B). As depicted in Figure 2A, two-way ANOVA (region $\times$ drug) conducted on freezing levels on day 2 revealed a significant effect of the drug $\left(F_{(1,37)}=4.06\right.$, $P=0.05)$, the interaction between drug and region $\left(F_{(1,37)}=\right.$ $6.99, P<0.05)$, but not the region $\left(F_{(1,37)}=2.4\right.$, n.s. $)$, indicating that WIN had different effects in the different regions. In the BLA, an independent samples $t$-test revealed that WIN microinjected rats showed significantly less freezing levels on day 2 compared with the vehicle group $\left(t_{(18)}=3.1, P<0.01\right)$, while this difference was not evident in the vSub $\left(t_{(19)}<1\right.$, n.s.). Hence, WIN impaired the acquisition/consolidation of CF when microinjected into the BLA. No differences in freezing levels were found between the groups on day 1 (data not shown).

As depicted in Figure 2B, a two-way ANOVA conducted on freezing levels on day 2 did not reveal a significant effect of the drug $\left(F_{(1,40)}=1.62\right.$, n.s. $)$, the region $\left(F_{(1,40)}=2.61\right.$, n.s. $)$, or the interaction between drug and region $\left(F_{(1,40)}=1.98\right.$, n.s. $)$. However, since rats microinjected with WIN into the vSub showed low freezing levels compared with the vehicle group, we used an independent-samples $t$-test on freezing levels. A $t$-test revealed a significant difference in freezing levels on day $2\left(t_{(24)}=2.09\right.$, $P<0.05)$, suggesting that WIN impaired the retrieval of CF when microinjected into the vSub.

To examine dose dependency, a lower dose of WIN (1 $\mu \mathrm{g} /$ side) was microinjected into the vSub prior to conditioning or prior to retrieval (data not shown). A two-way ANOVA conducted on freezing levels on day 2 showed no effect of the drug, region, or the interaction between drug and region $\left(F_{(1,23)}<1\right.$, n.s. $)$.

We then examined whether microinjecting a low and nonimpairing dose of the CB1 receptor antagonist AM251 (0.3 ng/ $0.5 \mu \mathrm{L}$ ) into the BLA/vSub would block the effects of WIN on acquisition (BLA) or retrieval (vSub) of CF. One-way ANOVA conducted on freezing levels on day 2 showed significant effect of the drug both in the BLA $\left(F_{(2,18)}=7.53, P<0.01\right.$; Fig. $\left.2 \mathrm{C}\right)$

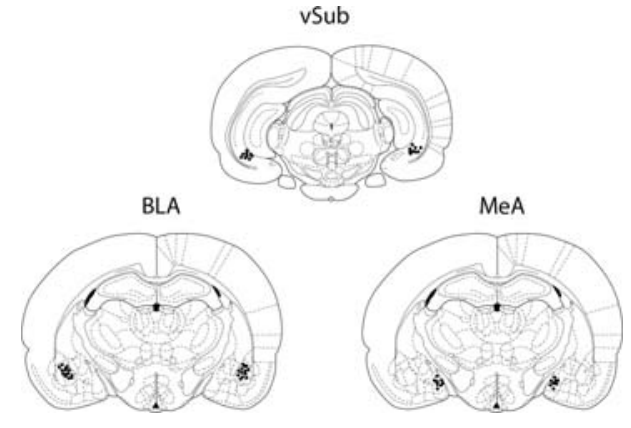

Figure 1. Representative schematic drawing of cannulae tips positions in the ventral subiculum (vSub), medial amygdala (MeA), and basolateral amygdala (BLA). Black circles show the representative locations of the cannulae tip at coronal views of the vSub (6.3 $\mathrm{mm}$ posterior to bregma), the MeA ( $2.5 \mathrm{~mm}$ posterior to bregma), or the BLA ( $3 \mathrm{~mm}$ posterior to bregma).

and the vSub $\left(F_{(2,16)}=11.56, P<0.01\right.$; Fig. 2D). Post hoc comparisons using Tukey revealed that the WIN group showed significantly less freezing then vehicle (BLA and vSub: $P<0.01$ ) and WIN + AM251 (BLA and vSub: $P<0.05$ ) groups while no significant difference was found between the vehicle and WIN + AM251 groups.

To exclude sensory-motor deficits as causes for the observed effects of WIN on performance rats were microinjected into the vSub or the BLA with WIN (vSub: $n=7$, BLA: $n=7$ ) or vehicle (vSub: $n=8$, BLA: $n=7$ ) and tested in the open field arena or the pain sensitivity test (Table 1). Two-way ANOVA conducted on distance covered in the open field did not reveal a significant effect of the drug or the interaction between drug and region $\left(F_{(1,25)}<1\right.$, n.s.). However, there was a significant main effect for region $\left(F_{(1,25)}=11.52, P<0.01\right)$. An independent-samples $t$-test revealed that the vSub group covered significantly less distance compared with the BLA group in the WIN $\left(t_{(12)}=2.25\right.$, $P<0.05)$ and the vehicle $\left(t_{(13)}=2.45, P<0.05\right)$-treated rats.

Two-way ANOVA conducted on the number of rearings and the time spent in the center did not reveal a significant effect of the drug (rearing: $F_{(1,25)}<1$, n.s.; time in center: $F_{(1,25)}=1.30$, n.s.), the region (rearing: $F_{(1,25)}=2.7$, n.s.; time in center: $F_{(1,25)}=1.92$, n.s.), or the interaction between drug and region $\left(F_{(1,25)}<1\right.$, n.s. $)$. Hence, microinjecting WIN into the vSub or the BLA did not affect anxiety levels as measured by the number of rearings and time spent in the center.

A two-way ANOVA conducted on pain sensitivity threshold did not reveal a significant effect of the drug $\left(F_{(1,20)}<1\right.$, n.s.), the region or the interaction between drug and region $\left(F_{(1,20)}<\right.$ 1 , n.s.) ( $n=6$ each).

To examine the effects of WIN on SD, rats were microinjected into the vSub or the MeA with WIN or vehicle before the sample phase (Fig. 3A) or before the choice phase (Fig. 3B). As depicted in Figure 3A, a two-way ANOVA conducted on discrimination index on choice day revealed a significant effect of the drug $\left(F_{(1,29)}=22.76, P<0.001\right)$, but not the region or the interaction between drug and region $\left(F_{(1,29)}<1\right.$, n.s.). No differences in total exploration time were observed during day 1 (data not shown). WIN microinjected into the vSub $\left(t_{(17)}=3.78, P<0.01\right)$ and the MeA $\left(t_{(12)}=3.32, P<0.01\right)$ resulted in less exploration of the novel juvenile on day 2 compared with the vehicle group.

WIN microinjection into the $B L A$ prior to acquisition did not affect performance on day $2\left(t_{(12)}<1\right.$, n.s., data not shown), suggesting that cannabinoid activation in the BLA does not affect the acquisition/consolidation of SD. 

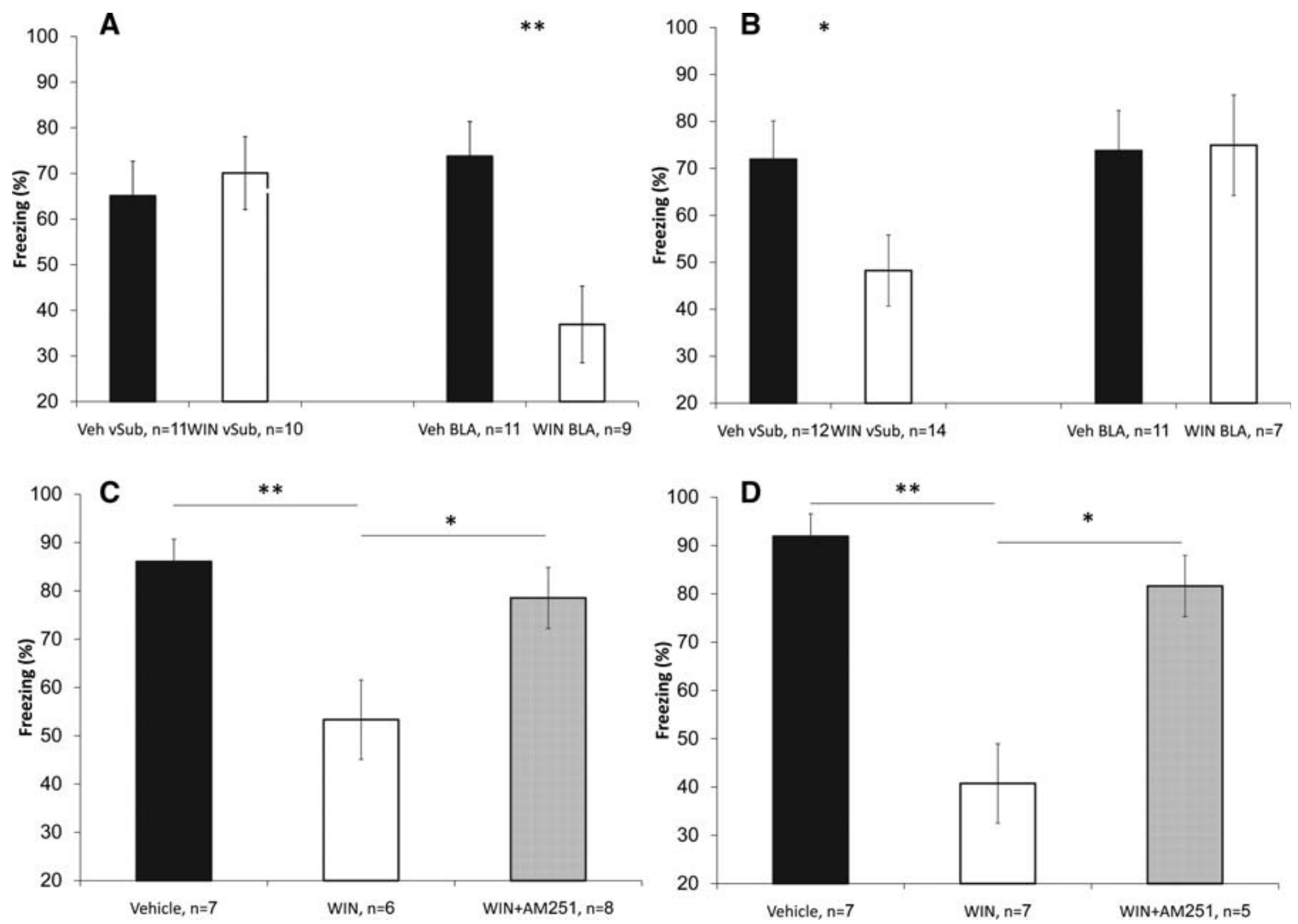

Figure 2. The effects of WIN 55,212-2 microinjected into the ventral subiculum (vSub) or the basolateral amygdala (BLA) on contextual fear (CF) acquisition/consolidation and retrieval. (A) Rats were microinjected with WIN $(5 \mu \mathrm{g} / \mathrm{side})$ or vehicle into the vSub or the BLA 20 min prior to conditioning on day 1. WIN microinjected into the $B L A$ before conditioning impairs the acquisition/consolidation of CF compared with the vehicle group. ${ }^{* *} P<0.01$, WIN BLA different from Veh BLA. Data represent the means \pm SEM. (B) Rats were microinjected with WIN $(5 \mu \mathrm{g} /$ side) or vehicle into the vSub or the BLA 20 min prior to retrieval on day 2 . WIN microinjected into the $v S u b$ before behavioral testing impairs the retrieval of CF compared with the vehicle group. ${ }^{*} P<$ 0.05 , WIN vSub different from Veh vSub. Data represent the means \pm SEM. (C) Rats were microinjected with WIN (5 $\mu \mathrm{g} / \mathrm{side}), \mathrm{WIN}(5 \mu \mathrm{g} / \mathrm{side})+\mathrm{AM} 251$ $(0.3 \mathrm{ng} / \mathrm{side})$, or vehicle into the BLA 20 min prior to acquisition of CF. AM251, coadministered with WIN into the BLA, blocked the effect of WIN on acquisition/consolidation of CF. ${ }^{*} P<0.05$, WIN different from WIN + AM251; ${ }^{*} P<0.01$, WIN different from Vehicle. Data represent the means \pm SEM. (D) Rats were microinjected with WIN $(5 \mu \mathrm{g} /$ side), WIN $(5 \mu \mathrm{g} / \mathrm{side})+\mathrm{AM} 251(0.3 \mathrm{ng} / \mathrm{side})$ or vehicle into the vSub $20 \mathrm{~min}$ prior to retrieval of CF. AM251, coadministered with WIN into the vSub, blocked the effect of WIN on retrieval of CF. ${ }^{*} P<0.05$, WIN different from WIN + AM251; ${ }^{* *} P<0.01$, WIN different from Vehicle. Data represent the means \pm SEM.

To examine dose dependency, a lower dose of WIN (1 $\mu \mathrm{g} /$ side) was microinjected into the vSub or MeA prior to the sample phase. A two-way ANOVA conducted on the data showed no effect for the drug, region or the interaction between drug and region $\left(F_{(1,16)}<1\right.$, n.s.) (data not shown).

As depicted in Figure 3B, a two-way ANOVA conducted on discrimination index on day 2 revealed a significant effect for the drug $\left(F_{(1,26)}=14.15, P<0.01\right)$, but not for the region $\left(F_{(1,26)}=1.175\right.$, n.s. $)$, and not for the interaction $\left(F_{(1,26)}=2.61\right.$, n.s. $)$. In the vSub, an independent-samples $t$-test revealed that WIN microinjected rats spent significantly less time exploring the novel juvenile as compared with the vehicle group $\left(t_{(12)}=3.25, \quad P<0.01\right)$, showing that the drug impaired retrieval of SD. This however was not evident in the $\operatorname{MeA}\left(t_{(14)}=1.8\right.$, n.s. $)$.

We then examined whether microinjecting AM251 into the vSub/MeA would block the effects of WIN on acquisition of SD. One-way ANOVA conducted on discrimination index on day 2 showed significant effect of the drug in the vSub $\left(F_{(2,19)}=5.82\right.$, $P<0.05)$ and the MeA $\left(F_{(2,15)}=6.55, P<0.01\right)$ (Fig. 3C). Post hoc comparisons revealed that the WIN group showed significantly less discrimination levels than vehicle (vSub and MeA: $P<0.05$ ) and WIN + AM251 (vSub and MeA: $P<0.05$ ) groups while no significant difference was found between the vehicle and WIN + AM251 groups. Since no effect on retrieval was found for WIN in the MeA, the effects of WIN and AM251 were

Table 1. The effects of WIN 55,212-2 microinjected into the ventral subiculum (vSub) or the basolateral amygdala (BLA) on sensory-motor parameters

\begin{tabular}{lcccc}
\hline & Veh vSub & WIN vSub & Veh BLA & WIN BLA \\
\hline Time in the center & $10.87 \pm 3.36$ & $8.29 \pm 2.04$ & $7.71 \pm 1.45$ & $4.56 \pm 1.14$ \\
Number of rearings & $23 \pm 2.68$ & $24.43 \pm 3.64$ & $20.28 \pm 3.03$ & $19.25 \pm 3.07$ \\
Distance covered $(\mathrm{cm})$ & $1316.25 \pm 102.41$ & $1395 \pm 203.98$ & $1678.57 \pm 261.56$ & $1476.44 \pm 223.24$ \\
$\begin{array}{l}\text { Pain threshold for foot } \\
\text { shock (mA) }\end{array}$ & $0.27 \pm 0.03$ & $0.26 \pm 0.02$ & $0.32 \pm 0.04$ & $0.30 \pm 0.01$ \\
& & & & \\
\hline
\end{tabular}

WIN microinjected into the vSub (WIN vSub: $n=7$ ) or BLA (WIN BLA: $n=7$ ) had no effect on any of the parameters measured in the open-field test compared with the vehicle-treated rats (Veh vSub: $n=8$, Veh BLA, $n=7$ ), namely, time in the center, number of rearings, and the distance covered. Rats microinjected into the vSub or BLA with WIN showed similar pain sensitivity responses to electric footshock compared with the vehicle groups ( $n=6$ each). 

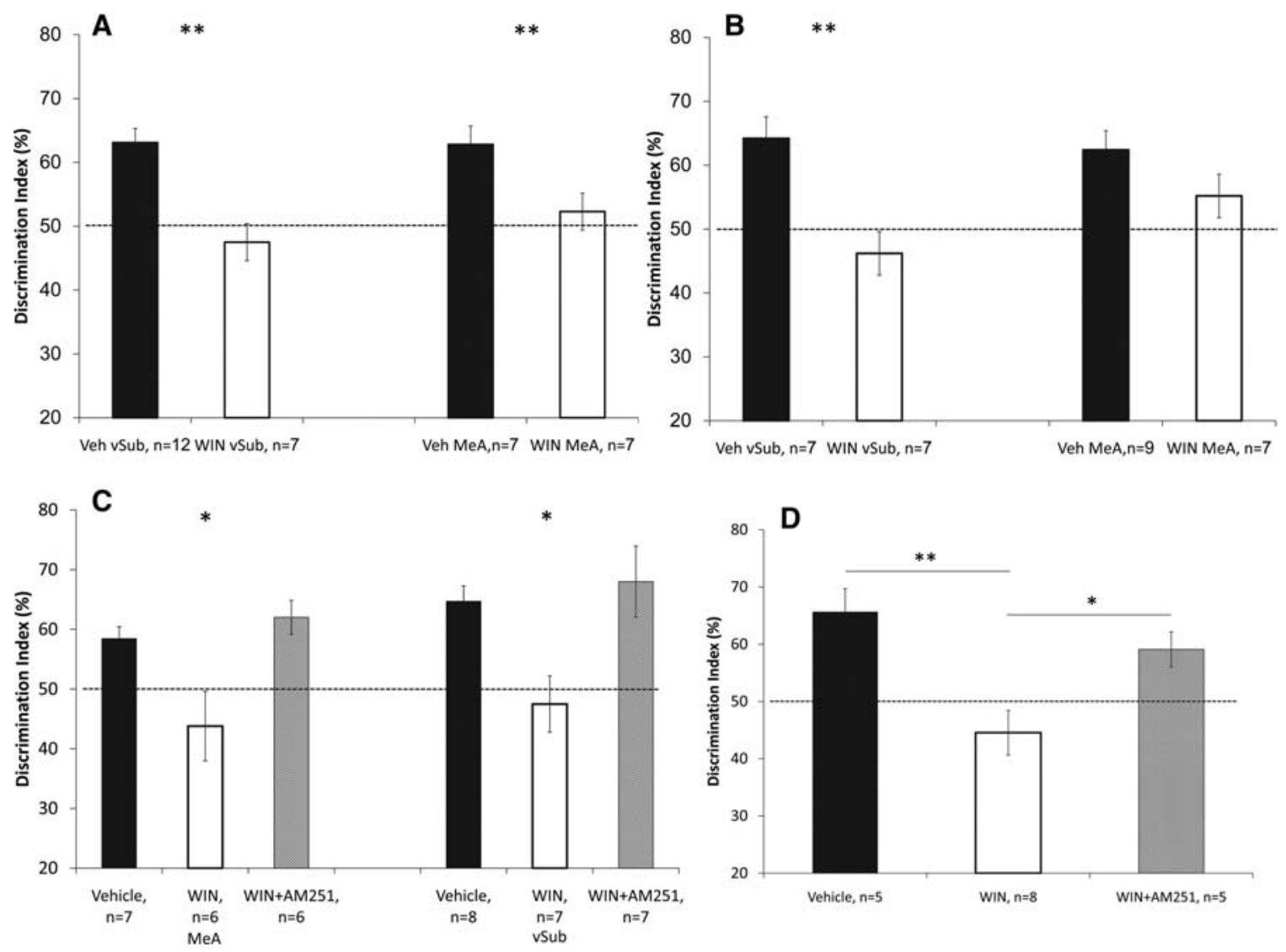

Figure 3. The effects of WIN 55,212-2 microinjected into the ventral subiculum (vSub) or the medial amygdala (MeA) on social discrimination (SD). (A) Rats were microinjected with WIN ( $5 \mu \mathrm{g} / \mathrm{side}$ ) or vehicle into the vSub or the MeA 20 min prior to the sample phase of the social discrimination task on day 1 . WIN microinjected into the vSub or the MeA impairs the acquisition of social discrimination compared with the vehicle groups. ${ }^{* *} P<0.01$ : Veh different from WIN. Data represent the means \pm SEM. (B) Rats were microinjected with WIN $(5 \mu \mathrm{g} /$ side) or vehicle into the vSub or the MeA prior to exposure to the familiar and novel juveniles of the social discrimination task on day 2 (choice phase). WIN microinjected into the vSub before behavioral testing impairs the retrieval of social discrimination compared with the vehicle group. ${ }^{* *} P<0.01$ : Veh vSub different from WIN vSub. Data represent the

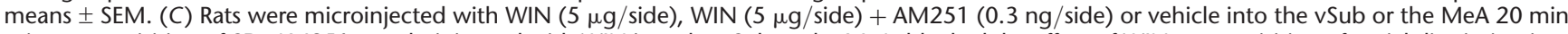
prior to acquisition of SD. AM251, coadministered with WIN into the vSub or the MeA, blocked the effect of WIN on acquisition of social discrimination. ${ }^{*} P<0.05$, WIN different from Vehicle and WIN + AM251. Data represent the means \pm SEM. (D) Rats were microinjected with WIN (5 $\mu \mathrm{g} /$ side), WIN (5 $\mu \mathrm{g} / \mathrm{side})+\operatorname{AM} 251(0.3 \mathrm{ng} / \mathrm{side})$ or vehicle into the vSub $20 \mathrm{~min}$ prior to retrieval of SD. AM251, coadministered with WIN into the vSub, blocked the effect of WIN on retrieval of social discrimination. ${ }^{*} P<0.05$, WIN different from WIN + AM251; ${ }^{* *} P<0.01$, WIN different from Vehicle. Data represent the means \pm SEM.

examined only in the vSub (Fig. 3D), where one-way ANOVA showed a significant effect for drug $\left(F_{(2,15)}=8.33, P<0.01\right)$. Post hoc comparisons revealed that the WIN group showed significantly less discrimination levels than vehicle $(P<0.01)$ and WIN + AM251 $(P<0.05)$ groups while no significant difference was found between the vehicle and WIN + AM251 groups.

To exclude the possibility that WIN affected social interaction per se rather than memory, rats were microinjected with WIN or Vehicle into the MeA and vSub prior to a social interaction test session. A two-way ANOVA conducted on the frequency of social and a-social behaviors did not reveal a significant effect of the drug, the region, or the interaction between drug and region $\left(F_{(1,26)}=3.52\right.$, n.s.) (data not shown).

Our findings suggest differential effects of cannabinoid receptor activation on learning and memory that are task-, brain region-, and memory stage-dependent.

In the CF task, WIN into the BLA impaired acquisition but not retrieval, whereas in the vSub, the opposite was observed. In the nonaversive SD task, WIN into the vSub impaired both acquisition and retrieval, while in the MeA it impaired acquisition only.
However, when microinjecting the drug before encoding, WIN may also impair memory by affecting consolidation processes. When the CB1 receptor antagonist AM251 was coadministered with WIN into the BLA, vSub or MeA, it blocked the effects of WIN on CF and SD, suggesting that the impairing effects of WIN are mediated via an activation of CB1 receptors.

Control experiments demonstrated that the effects of WIN cannot be attributed to sensorimotor deficits as WIN microinjected into the vSub or the BLA had no effect on anxiety levels, locomotion or pain sensitivity threshold.

It has been shown that the role of the dorsal hippocampus in contextual fear conditioning is different than the role of the ventral hippocampus (Phillips and Ledoux 1994; Bast et al. 2003). Consistent with our findings, Biedenkapp and Rudy (2008) have shown that when the vSub is disabled, the extra-hippocampal system (i.e., the amygdala) can support contextual fear formation, given that the deactivation occurred before and not after conditioning. Using the inhibitory avoidance task, Campolongo et al. (2009) found that WIN microinjected into the BLA prior to training induced a dose-dependent enhancement of 48-h retention. 
However, there are significant differences in task requirements between inhibitory avoidance and CF that also exist in the neural substrates involved in the task, pointing to a differential effect of cannabinoids that is task dependent.

Unlike the aversive fear conditioning task, SD is considered neutral or even rewarding. This finding was established using both conditioned place preference paradigms and T-maze learning rewarded by social interaction (Taylor 1981; Van den Berg et al. 1999). We aimed to minimize test aversiveness in SD experiments by testing rats habituated to the arena under dim light and using a juvenile conspecific, conditions associated with lower anxiety levels (File and Seth 2003; Haller et al. 2004; Jacob et al. 2009).

It has been suggested that the MeA modulates the initial social encounter and formation of social memory and its activation upon signals arriving from the olfactory bulb is crucial for such memories to form (Ferguson et al. 2001). However, contradictory findings exist regarding the role of the vSub in social recognition and SD. Cytotoxic lesions of the hippocampus caused a mild impairment in SD memory (Bannerman et al. 2002) with no impairment of social recognition in socially housed rats (Squires et al. 2006).

It has been recently suggested that the neural processes underlying emotional memory formation (such as fear and extinction memories) and nonemotional memories are differentially sensitive to cannabinoid receptor activation (Chhatwal and Ressler 2007). Most studies have shown that CB1 agonists impair performance in several nonaversive hippocampal- and prefrontal-dependent learning tasks (for review: Hampson and Deadwyler 1999; Egerton et al. 2006). However, an increasing number of studies demonstrate that the cannabinoid system is critical for the encoding of emotional memory and for the extinction of fear-related memories (Marsicano et al. 2002; Chhatwal et al. 2005; Laviolette and Grace 2006; Viveros et al. 2007; GanonElazar and Akirav 2009; Abush and Akirav 2010). CB1-deficient mice show impaired auditory fear extinction, with unaffected memory acquisition and consolidation (Marsicano et al. 2002), whereas systemic and local cannabinoid receptor activation facilitate fear extinction (Chhatwal et al. 2005; Pamplona et al. 2006, 2008; Abush and Akirav 2010). So far, however, these findings on the involvement of CB1 receptors in extinction processes seem limited to aversive learning tasks, indicated by studies showing that $\mathrm{CB} 1$ receptors are not required in appetitive tasks (Hölter et al. 2005; Niyuhire et al. 2007).

Although we used a small volume of infusion $(0.5 \mu \mathrm{L}$ or $0.3 \mu \mathrm{L}$ ), the possibility of injection spread to other structures, especially from the BLA to the central amygdala nucleus and from the vSub to the CA1 cannot be completely ruled out. Yet, $\mathrm{CB} 1$ receptors are expressed at high levels in the BLA but their expression in the central amygdala is less clear (Herkenham et al. 1990; Tsou et al. 1998; Katona et al. 2001; Cota et al. 2007). Yet, recently Kamprath et al. (2011) have shown that intracentral amygdala application of AM251 resulted in an acutely increased fear response in an auditory fear conditioning paradigm. Other studies used similar or higher volumes targeted at the vSub (Sun and Rebec 2003; Biedenkapp and Rudy 2008) or BLA (Shors and Mathew 1998; Duvarci et al. 2006).

Here we examined the effects of exogenously administrated cannabinoids on learning and memory processes as we aimed to examine whether activating $\mathrm{CB} 1 / 2$ receptors would differentially affect memory processes in a neutral vs. an aversive task in the hippocampus and the amygdala. The administration of exogenous cannabinoids such as WIN or delta-9-THC activates $\mathrm{CB} 1 / 2$ receptors and intrinsically lacks the spatial and temporal specificity of endogenously produced endocannabinoids (Marsicano and Lutz 2006). Hence, it should be noted that exogenous cannabinoids may lead to subtle differences or even an opposite effect on learning and memory than drugs that work on endocannabinoid synthesizing and degradation systems.

Our findings suggest that the acquisition/consolidation and the retrieval of aversive and nonaversive memories may show sensitivity to cannabinoids. This sensitivity is determined by the nature of the task, the memory stage that is under investigation, and the brain area involved.

\section{Acknowledgments}

This research was supported by The Israel Science Foundation (grant No. 222/08 to I.A).

\section{References}

Abush H, Akirav I. 2010. Cannabinoids modulate hippocampal memory and plasticity. Hippocampus 20: $1126-1138$.

Bannerman DM, Lemaire M, Yee BK, Iversen SD, Oswald CJP, Good MA, Rawlins JN. 2002. Selective cytotoxic lesions of the retrohippocampal region produce a mild deficit in social recognition memory. Exp Brain Res 142: $395-401$.

Bast T, Zhang WN, Feldon J. 2003. Dorsal hippocampus and classical fear conditioning to tone and context in rats: Effects of local NMDA-receptor blockade and stimulation. Hippocampus 13: 657-675.

Biedenkapp JC, Rudy JW. 2008. Hippocampal and extrahippocampal systems compete for control of contextual fear: Role of ventral subiculum and amygdala. Learn Mem 16: 38-45.

Bielsky IF, Young LJ. 2004. Oxytocin, vasopressin, and social recognition in mammals. Peptides 25: 1565-1574.

Campolongo P, Roozendaal B, Trezza V, Hauer D, Schelling G, McGaugh JL, Cuomo V. 2009. Endocannabinoids in the rat basolateral amygdala enhance memory consolidation and enable glucocorticoid modulation of memory. Proc Natl Acad Sci 106: 4888-4893.

Chhatwal JP, Ressler KJ. 2007. Modulation of fear and anxiety by the endogenous cannabinoid system. CNS Spectr 12: 211-220.

Chhatwal JP, Davis M, Maguschak KA, Ressler KJ. 2005. Enhancing cannabinoid neurotransmission augments the extinction of conditioned fear. Neuropsychopharmacology 30: 516-524.

Clarke JR, Rossato JI, Monteiro S, Bevilaqua LRM, Izquierdo I, Cammarota M. 2008. Posttraining activation of CB1 cannabinoid receptors in the CA1 region of the dorsal hippocampus impairs object recognition long-term memory. Neurobiol Learn Mem 90: $374-381$.

Cota D, Steiner MA, Marsicano G, Cervino C, Herman JP, Grubler Y, Grübler Y, Stalla J, Pasquali R, Lutz B, et al. 2007. Requirement of cannabinoid receptor type 1 for the basal modulation of hypothalamic-pituitary-adrenal axis function. Endocrinology 148: $1574-1581$

Da Silva GE, Takahashi RN. 2002. SR 141716A prevents [delta] 9tetrahydrocannabinol-induced spatial learning deficit in a morris-type water maze in mice. Prog Neuropsychopharmacol Biol Psychiatry 26: $321-325$.

de Oliveira Alvares L, de Oliveira LF, Camboim C, Diehl F, Genro BP, Lanziotti VB, Quillfeldt JA. 2005. Amnestic effect of intrahippocampal AM251, a CB1-selective blocker, in the inhibitory avoidance, but not in the open field habituation task, in rats. Neurobiol Learn Mem 83: $119-124$.

Duvarci S, Mamou CB, Nader K. 2006. Extinction is not a sufficient condition to prevent fear memories from undergoing reconsolidation in the basolateral amygdala. Eur J Neurosci 24: 249-260.

Egerton A, Allison C, Brett RR, Pratt JA. 2006. Cannabinoids and prefrontal cortical function: Insights from preclinical studies. Neurosci Biobehav Rev 30: 680-695.

Fanselow MS. 1998. Pavlovian conditioning, negative feedback, and blocking: Mechanisms that regulate association formation. Neuron 20: $625-627$.

Ferguson JN, Aldag JM, Insel TR, Young LJ. 2001. Oxytocin in the medial amygdala is essential for social recognition in the mouse. J Neurosci 21: $8278-8285$

File SE, Seth P. 2003. A review of 25 years of the social interaction test. Eur J Pharmacol 463: 35-53.

Ganon-Elazar E, Akirav I. 2009. Cannabinoid receptor activation in the basolateral amygdala blocks the effects of stress on the conditioning and extinction of inhibitory avoidance. J Neurosci 29: 11078-11088.

Haller J, Varga B, Ledent C, Barna I, Freund TF. 2004. Context-dependent effects of CB1 cannabinoid gene disruption on anxiety-like and social behavior in mice. Eur J Neurosci 19: 1906-1912. 
Hampson RE, Deadwyler SA. 1999. Cannabinoids, hippocampal function and memory. Life Sci 65: 715-723.

Herkenham M, Lynn AB, Little MD, Johnson MR, Melvin LS, de Costa BR, Rice KC. 1990. Cannabinoid receptor localization in brain. Proc Natl Acad Sci 87: 1932-1936.

Hölter SM, Kallnik M, Wurst W, Marsicano G, Lutz B, Wotjak CT. 2005. Cannabinoid CB1 receptor is dispensable for memory extinction in an appetitively-motivated learning task. Eur J Pharmacol 510: 69-74.

Jacob W, Yassouridis A, Marsicano G, Monory K, Lutz B, Wotjak CT. 2009. Endocannabinoids render exploratory behaviour largely independent of the test aversiveness: Role of glutamatergic transmission. Gene Brain Behav 8: 685-698.

Kamprath K, Romo-Parra H, Häring M, Gaburro S, Doengi M, Lutz B, Pape HC. 2011. Short-term adaptation of conditioned fear responses through endocannabinoid signaling in the central amygdala. Neuropsychopharmacology 36: 652-663.

Katona I, Rancz EA, Acsady L, Ledent C, Mackie K, Hajos N, Freund TF. 2001. Distribution of CB1 cannabinoid receptors in the amygdala and their role in the control of GABAergic transmission. J Neurosci 21: 9506-9518.

Kogan JH, Frankland PW, Silva AJ. 2000. Long-term memory underlying hippocampus-dependent social recognition in mice. Hippocampus 10: $47-56$.

Laviolette SR, Grace AA. 2006. Cannabinoids potentiate emotional learning plasticity in neurons of the medial prefrontal cortex through basolateral amygdala inputs. J Neurosci 63: 1597-1613.

LeDoux J. 2003. The emotional brain, fear, and the amygdala. Cell Mol Neurobiol 23: 727-738.

Lichtman AH, Martin BR. 1996. $\Delta$ 9-tetrahydrocannabinol impairs spatial memory through a cannabinoid receptor mechanism. Psychopharmacology 126: 125-131.

Maren S, Quirk GJ. 2004. Neuronal signaling of fear memory. Nat Rev Neurosci 5: 844-852.

Marsicano G, Lutz B. 2006. Neuromodulatory functions of the endocannabinoid system. J Endocrinol Invest 29: 27-46.

Marsicano G, Wotjak CT, Azad SC, Bisogno T, Rammes G, Cascio MG Hermann H, Tang J, Hofmann C, Zieglgänsberger W, et al. 2002. The endogenous cannabinoid system controls extinction of aversive memories. Nature 418: 530-534.

Niyuhire F, Varvel SA, Thorpe AJ, Stokes RJ, Wiley JL, Lichtman AH. 2007. The disruptive effects of the CB 1 receptor antagonist rimonabant on extinction learning in mice are task-specific. Psychopharmacology 191: 223-231.

Pamplona FA, Takahashi RN. 2006. WIN 55212-2 impairs contextual fear conditioning through the activation of CB1 cannabinoid receptors. Neurosci Lett 397: 88-92.

Pamplona FA, Prediger RD, Pandolfo P, Takahashi RN. 2006. The cannabinoid receptor agonist WIN 55,212-2 facilitates the extinction of contextual fear memory and spatial memory in rats.

Psychopharmacology 188: 641-649.
Pamplona FA, Bitencourt RM, Takahashi RN. 2008. Short- and long-term effects of cannabinoids on the extinction of contextual fear memory in rats. Neurobiol Learn Mem 90: 290-293.

Phillips RG, LeDoux JE. 1994. Lesions of the dorsal hippocampal formation interfere with background but not foreground contextual fear conditioning. Learn Mem 1: 34-44.

Robinson L, Goonawardena AV, Pertwee R, Hampson RE, Platt B, Riedel G. 2010. WIN55, 212-2 induced deficits in spatial learning are mediated by cholinergic hypofunction. Behav Brain Res 208: $584-592$.

Shachar-Dadon A, Schulkin J, Leshem M. 2009. Adversity before conception will affect adult progeny in rats. Dev Psychol 45: 9-16.

Shors TJ, Mathew PR. 1998. NMDA receptor antagonism in the lateral basolateral but not central nucleus of the amygdala prevents the induction of facilitated learning in response to stress. Learn Mem 5: $220-230$.

Squires AS, Peddle R, Milway SJ, Harley CW. 2006. Cytotoxic lesions of the hippocampus do not impair social recognition memory in socially housed rats. Neurobiol Learn Mem 85: 95-101.

Sun W, Rebec GV. 2003. Lidocaine inactivation of ventral subiculum attenuates cocaine-seeking behavior in rats. J Neurosci 23: $10258-10264$.

Suzuki A, Josselyn SA, Frankland PW, Masushige S, Silva AJ, Kida S. 2004 Memory reconsolidation and extinction have distinct temporal and biochemical signatures. J Neurosci 24: 4787-4795.

Taylor GT. 1981. Fear and affiliation in domesticated male rats. J Comp Physiol Psychol 95: 685-693.

Tsou K, Brown S, Sanudo-Pena MC, Mackie K, Walker JM. 1998. Immunohistochemical distribution of cannabinoid CB1 receptors in the rat central nervous system. Neuroscience 83: 393-411.

Van den Berg CL, Hol T, Van Ree JM, Spruijt BM, Everts H, Koolhaas JM. 1999. Play is indispensable for an adequate development of coping with social challenges in the rat. Dev Psychobiol 34: $129-138$.

van Wimersma Greidanus TB, Maigret C. 1996. The role of limbic vasopressin and oxytocin in social recognition. Brain Res 713: $153-159$.

Varvel SA, Anum EA, Lichtman AH. 2005. Disruption of CB 1 receptor signaling impairs extinction of spatial memory in mice. Psychopharmacology 179: 863-872.

Viveros MP, Marco EM, Llorente R, Lopez-Gallardo M. 2007. Endocannabinoid system and synaptic plasticity: Implications for emotional responses. Neural Plast 52908: 1-12.

Wise LE, Thorpe AJ, Lichtman AH. 2009. Hippocampal CB1 receptors mediate the memory impairing effects of $\Delta 9$-tetrahydrocannabinol. Neuropsychopharmacology 34: 2072-2080.

Received December 13, 2010; accepted in revised form January 18, 2011. 


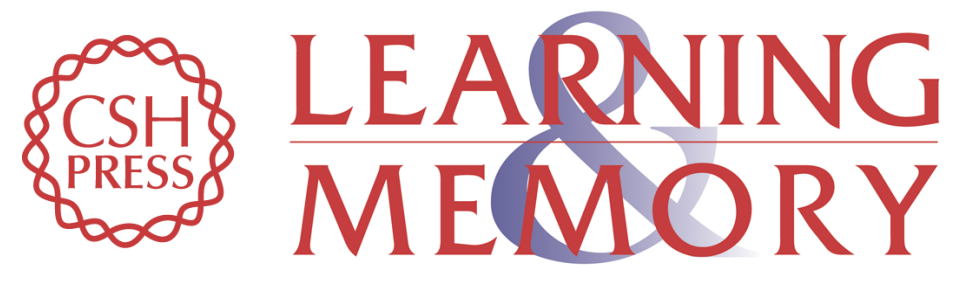

\section{Differential effects of cannabinoid receptor agonist on social discrimination and contextual fear in amygdala and hippocampus}

Amir Segev and Irit Akirav

Learn. Mem. 2011, 18:

Access the most recent version at doi:10.1101//m.2110511

References This article cites 50 articles, 10 of which can be accessed free at: http://learnmem.cshlp.org/content/18/4/254.full.html\#ref-list-1

License

Email Alerting

Receive free email alerts when new articles cite this article - sign up in the box at the Service top right corner of the article or click here. 